\title{
A NEW GOLDEN YELLOW SMALL-FLOWERED CYRTOCHILUM SPECIES (ORCHIDACEAE: ONCIDIINAE) FROM PERU
}

\author{
Stig Dalström ${ }^{1,2,3,5} \&$ Delsy Trujillo ${ }^{4}$ \\ 12304 Ringling Boulevard, unit 119, Sarasota FL 34237, U.S.A. \\ ${ }^{2}$ Lankester Botanical Garden, University of Costa Rica, Cartago, Costa Rica \\ ${ }^{3}$ National Biodiversity Centre, Serbithang, Bhutan \\ ${ }^{4}$ Herbario San Marcos (USM), Museo de Historia Natural de la Universidad Nacional Mayor de San \\ Marcos, Jesús María 15072, Lima, Perú \\ ${ }^{5}$ Author for correspondence: stigdalstrom@gmail.com
}

\begin{abstract}
A new golden yellow small-flowered species of Cyrtochilum is described and illustrated with a line drawing and photographs. It is compared with superficially similar species in the C. aureum complex, in which the new species differs by the lack of lacerate column wings typical for that group. It is distinguished from all other known small-flowered Cyrtochilum species by the golden yellow color in combination with the distinctly pandurate lip lamina where the front lobe is wider than the basal lobes combined.
\end{abstract}

Key Words: Ancash, Cyrtochilum, new species, Oncidiinae, Peru

Introduction. While exploring the western slopes of the Peruvian Andes the authors have observed that the climate there is markedly less humid than on the eastern slopes. This appears to be the effect from the Humboldt Current that brings cold water from the Antarctic region up along the Peruvian coast, which in turn produces less evaporation of water. This climatologic and hydrologic fact simply means less rain over the coastal area. Being more densely populated than the eastern slopes, it also means a heavier toll on existing fresh water sources and on other natural resources such as original forests. Slash and burn techniques to clear land for pastures, and mining operations are other human activities that disturb the natural orders. This has created a landscape commonly dominated by shrubs and grasslands. The orchid diversity in these plant communities therefore seem to be relatively poor, according to the authors' observations. Species of the Oncidiinae appear to be scarce in this region in contrast to the eastern slopes of the Peruvian Andes where this subtribe is highly diverse. At elevations above $3000 \mathrm{~m}$ only two Oncidiinae species have been currently recorded from the central-northern highlands of Peru (Departments of Ancash and La Libertad): Trichoceros tupaipi Rchb.f. and Cyrtochilum cochleatum (Lindl.) Dalström (Fig. 1) (Trujillo 2012). This latter species has been misidentified by several authors and reported as "Odontoglossum mystacinum (Lindl.) Lindl.” (Weberbauer 1945), “O. rigidum Lindl.”, (Kolff \& Kolff 1997; Smith 1988) and C. aureum (Lindl.) Senghas (Trujillo 2012, 2013). The C. aureum complex consists of four hitherto described species: C. aureum, C. cochleatum, C. mystacinum, $C$. rigidum (Lindl,) Dalström (Dalström 2013), and one undescribed species from the Department of Huanuco (in cultivation by the Perúflora nursery). During a recent revision of the Cyrtochilum specimens of the David Bennett Collection kept at the herbarium of the National Agrarian University La Molina in Lima (MOL), a new species with golden yellow flowers from the highlands of Ancash was found that superficially resembles the members of the $C$. aureum complex but differs in not having distinct lacerate column wings and by having a distinctly pandurate lip lamina, and is described here.

\section{TAXONOMIC TREATMENT}

Cyrtochilum panduratum Dalström \& D.Trujillo, sp. nov. (Fig. 2-4).

TYPE: Peru. Ancash: Yungay; Huascarán National Park, Lago Llanganuco area on rocky slopes, 3800 m, 20 Nov. 1998, M. León \& B. Collantes 2825 (Herbarium Bennettianum 7848) (holotype: MOL). 


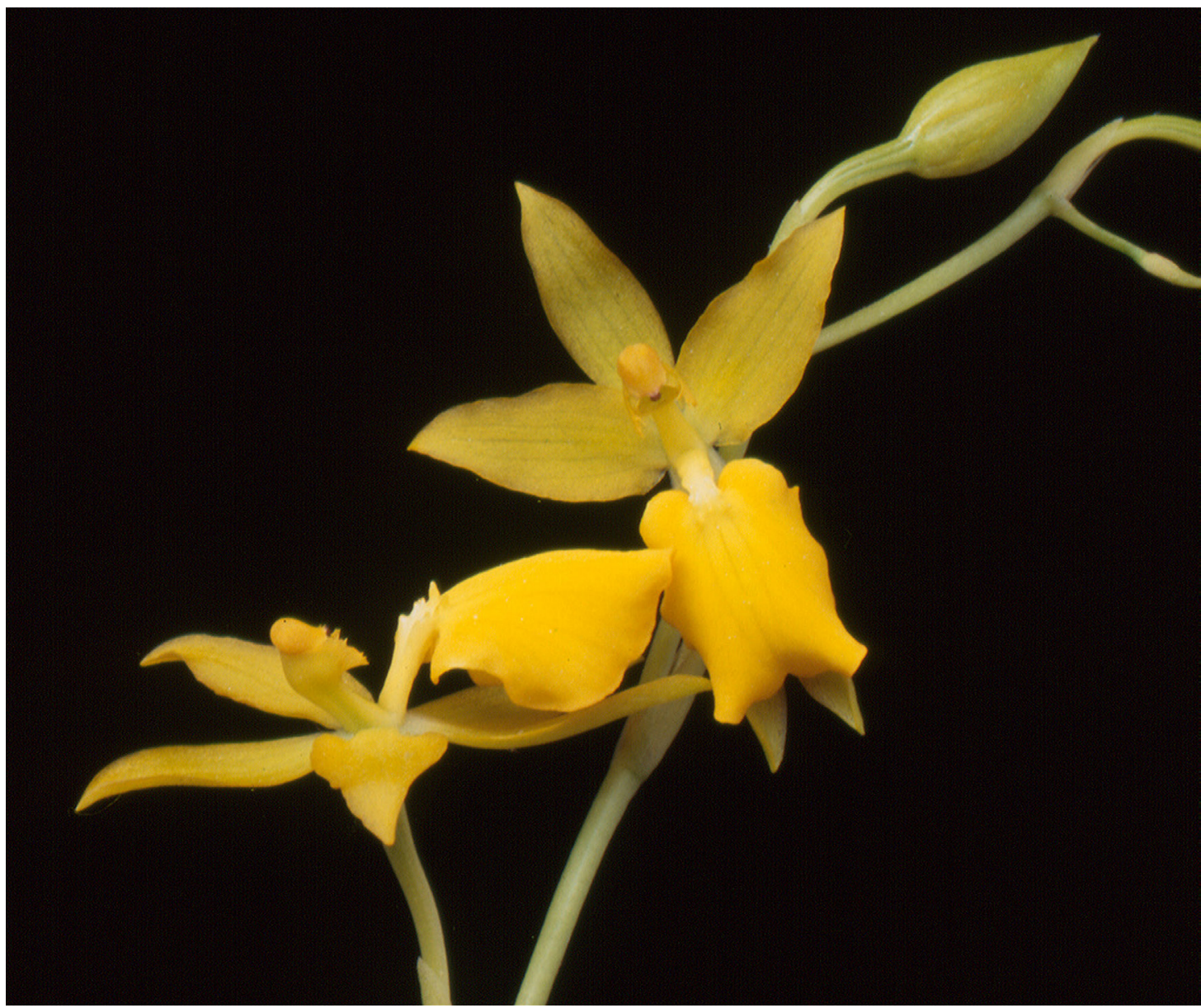

Figure 1. Cyrtochilum cochleatum from Peru, Dept. La Libertad. Photo by D. Trujillo.

Diagnosis: Cyrtochilum panduratum is distinguished from the species in the superficially similar $C$. aureum complex by the combination of the wingless column and the distinctly pandurate lip lamina.

Terrestrial or lithophytic herb. Roots thick, ca. 3-4 $\mathrm{mm}$ in diameter. Pseudobulbs caespitose, ovoid elongate, $c a .9 \times 3 \mathrm{~cm}$, bifoliate or trifoliate, surrounded basally by 5 to 6 distichous sheaths, the uppermost foliaceous. Leaves subpetiolate, conduplicate, elliptic to obovate-lanceolate, obtuse apiculate, $19-28 \times 1.5-2.0 \mathrm{~cm}$. Inflorescence erect, an almost straight to indistinctly flexuous panicle with many widely spaced, indistinctly flexuous 2-10 cm long side-branches, total length $118 \mathrm{~cm}$ long [according to the original collector's notes]. Inflorescence bracts and floral bracts similar, scale- like, appressed, acute, $2-15 \mathrm{~mm}$ long. Pedicel with ovary 8-15 mm long. Flowers golden yellow; dorsal sepal unguiculate, obovate, indistinctly canaliculate, apiculate with 5 veins, $c a .8 \times 5 \mathrm{~mm}$; lateral sepals fused for $c a .1 / 3$ of their length then spreading, unguiculate, elliptic to indistinctly ovate and slightly oblique, indistinctly canaliculate, apiculate, with 5 veins, $c a .10 \times 4 \mathrm{~mm}$; petals shortly unguiculate, obliquely ovate, $c a .7 \times 4.5-5.0 \mathrm{~mm}$, with 5 veins; lip rigidly attached to the base of the column, unguiculate, broadly cuneate, pandurate, retuse, $c a$. $10-11 \times 6 \mathrm{~mm}$; callus with a fleshy elevated central ridge emerging at the base of the lip, extending to the constricted part of the lip lamina, consisting of a pair of parallel basal ridges, diverging into spreading rounded angles, with an intermediate pair of blunt and fleshy angles apically, and with a smaller, blunt 


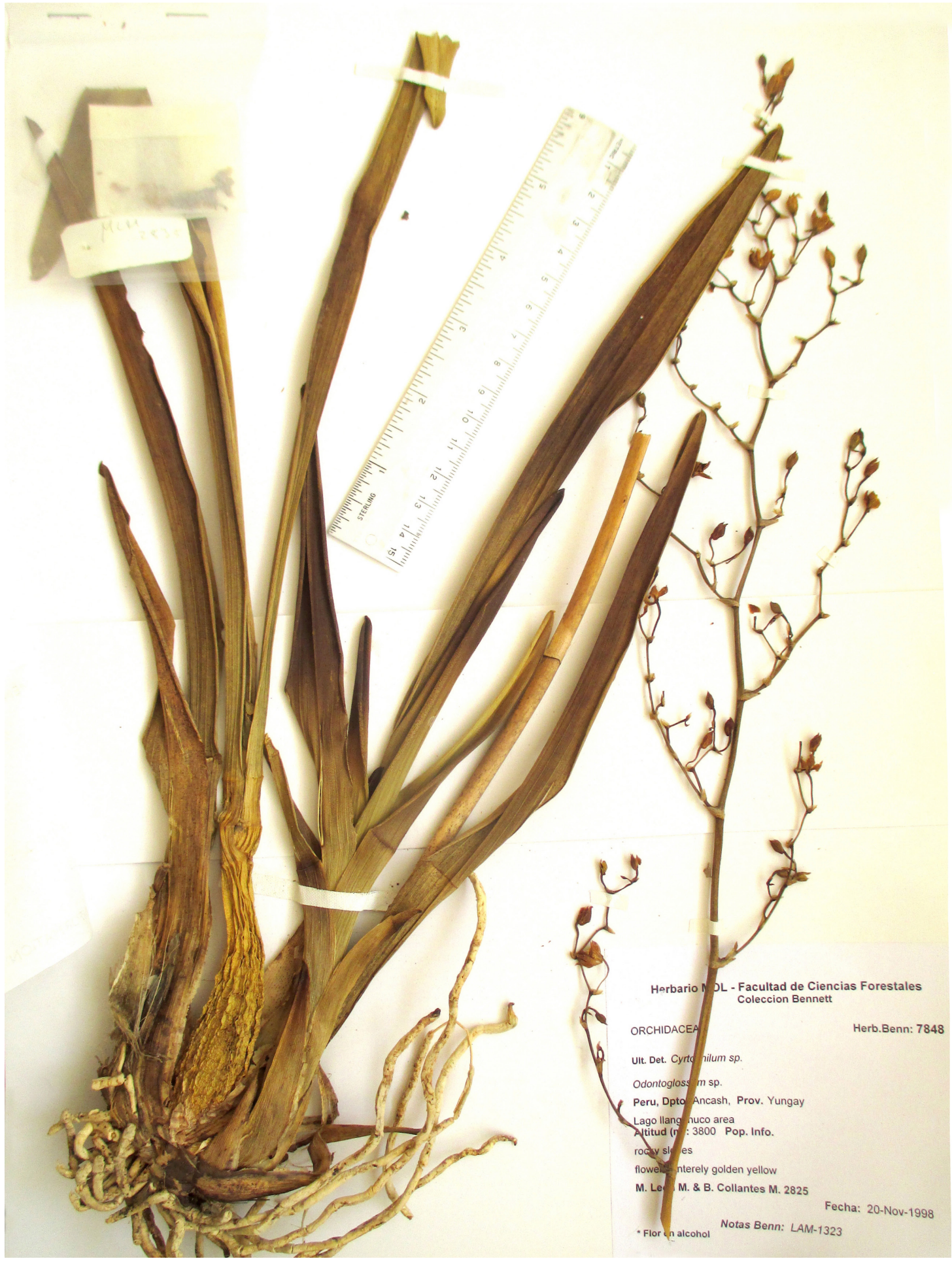

Figure 2. Holotype of Cyrtochilum panduratum Dalström \& D. Trujillo, M. León M. \& B. Collantes M. 2825 (MOL). Photo by D. Trujillo. 

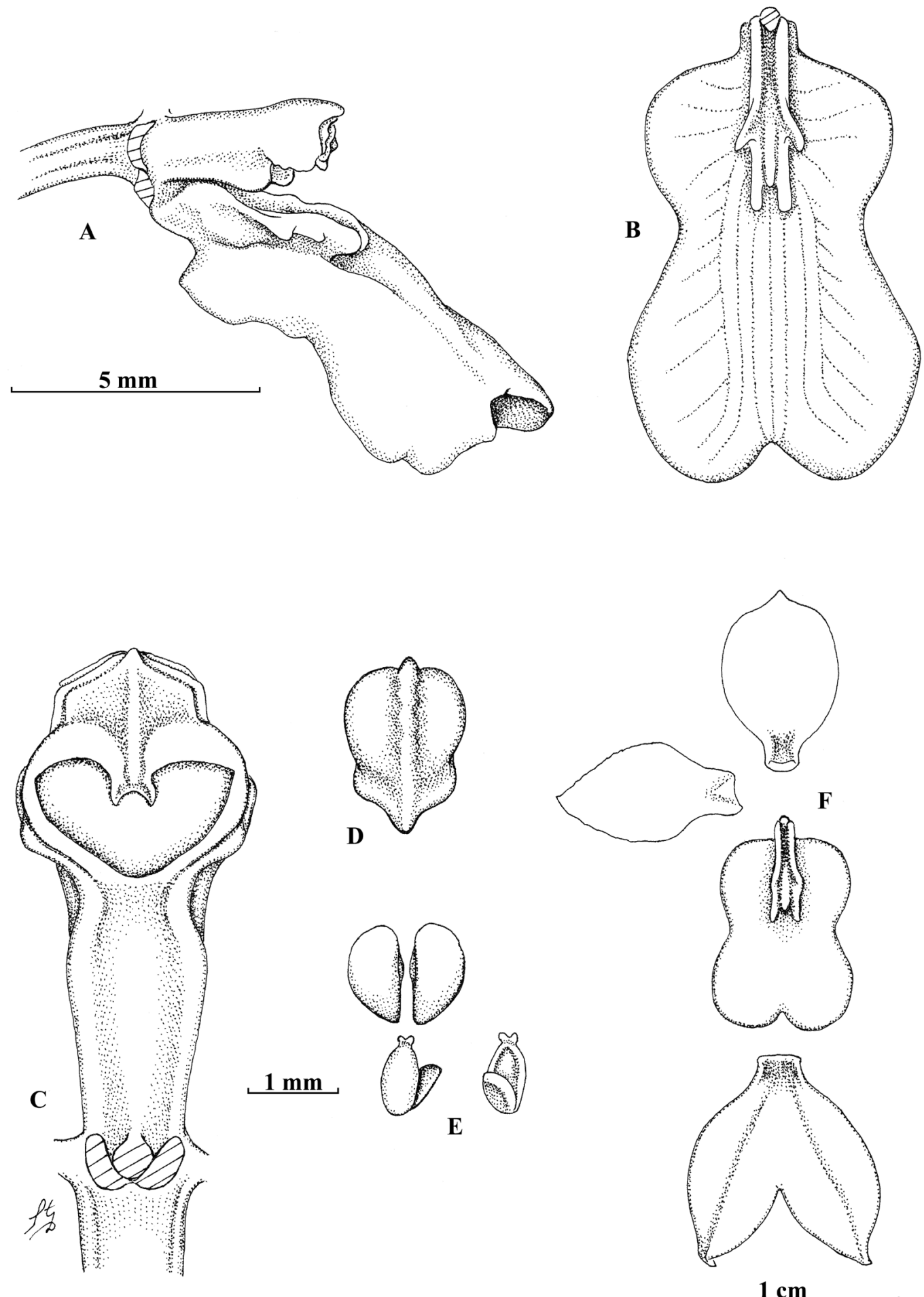

Figure 3. Cyrtochilum panduratum. A. Column and lip lateral view. B. Lip frontal view. C. Column ventral view. D. Anther cap. E. Pollinarium. F. Dissected flower. Drawn from the holotype by Stig Dalström. 
angle in between, ca. $4 \mathrm{~mm}$ long. Column clavate, straight, dorsally ridged, ventrally canaliculated with distinct apical angles below the stigmatic surface, and with a pair of apical more or less rounded wings, $c a$. $4 \mathrm{~mm}$ long; anther cap campanulate with a dorsal ridge, shortly rostrate; pollinarium of two obovoid, cleft/folded pollinia on a $c a$. $1 \mathrm{~mm}$ long ovate and strap-like stipe, longitudinally indistinctly revolute along the edges, on a pulvinate viscidium.

Paratype: No additional material seen.

Distribution: Cyrtochilum panduratum is only known from the type location, at high elevation rocky slopes in the area surrounding the Llanganuco lakes located in the Huascarán National Park, Department of Ancash, Peru.

Eтymology: Named in reference to the pandurate lip lamina.

From a floral morphology aspect Cyrtochilum panduratum does not seem to have any close relatives that it can be confused with. The combination of the distinctly pandurate lip lamina with a front lobe wider than the rounded basal lobes combined, together with the partially fused lateral sepals easily distinguish it from other yellow small-flowered species such as C. longipes Rchb.f. and C. soennemarkii Dalström, which have basal lobes wider than the front lobe. In overall morphological features Cyrtochilum panduratum is superficially similar to the yellow-colored $C$. cochleatum, C. mystacinum and C. rigidum but differs

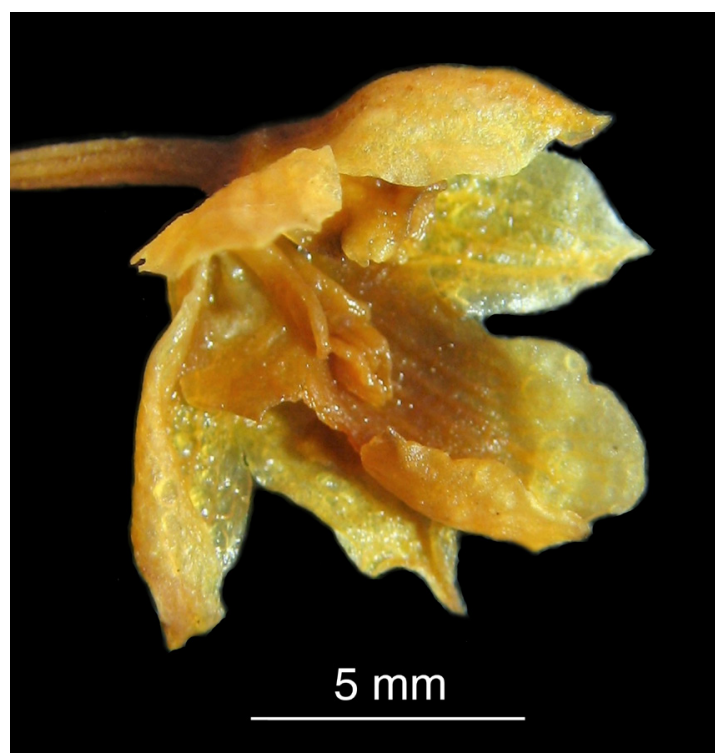

Figure 4. Close-up of a flower of C. panduratum, preserved in alcohol at MOL. Photo by D. Trujillo.

in not having any kind of apical column wings, versus large, lacerate and downward directed wings for the latter species.

ACKNOWLEDGMENTS. We thank the staff and curators of MOL for allowing access to their collections and permitting using photographs thereof for this article. Author Trujillo sincerely thanks Diana Bennett and Richard Bennett for access to David Bennett's notes and records. We also thank Wesley Higgins for viewing and commenting on the manuscript.

\section{LITERATURE CITED}

Dalström, S. (2013). The Golden Cyrtochilum. A study of Cyrtochilum aureum (Orchidaceae: Oncidiinae) and its allies and new taxonomic combinations. Orchids, 82(2), 114-118.

Kolff, H. \& Kolff, K. (1997). Flores silvestres de la Cordillera Blanca. Huaraz, Peru: Instituto de Montaña.

Smith, D. N. (1988). Flora and vegetation of the Huascaran National Park, Ancash, Peru: with preliminary taxonomic studies for a manual of the flora (Doctoral dissertation). Ames, Iowa, U.S.A.: Iowa State University.

Trujillo, D. (2012). High Andean orchids of Peru. Orchid Review, 120, 162-174.

Trujillo, D. (2013). Diversidad de orquídeas de las diferentes formaciones vegetales de los Andes Peruanos. Lankesteriana, 13(1-2), 103-111.

Weberbauer, A. (1945). El mundo vegetal de los Andes Peruanos. Estudio fitogeográfico. Lima, Peru: Ministerio de Agricultura. 
